\title{
Effects of the Tibetan High and the North Pacific High on the Occurrence of Hot or Cool Summers in Japan
}

\author{
Makoto Inoue ${ }^{1, *(D)}$, Atsushi Ugajin ${ }^{2,+}$, Osamu Kiguchi ${ }^{1}$, Yousuke Yamashita ${ }^{3}$, , Masashi Komine ${ }^{4}$ \\ and Shuji Yamakawa 5 \\ 1 Department of Biological Environment, Akita Prefectural University, Akita 010-0195, Japan; \\ o_kiguchi00120@akita-pu.ac.jp \\ 2 Graduate School of Bioresource Sciences, Akita Prefectural University, Akita 010-0195, Japan; \\ ugajin.atsushi@nies.go.jp \\ 3 National Institute for Environmental Studies, Tsukuba 305-8506, Japan; yamashita.yosuke@nies.go.jp \\ 4 Department of Biological Production, Akita Prefectural University, Akita 010-0195, Japan; \\ mkomine@akita-pu.ac.jp \\ 5 College of Humanities and Sciences, Nihon University, Tokyo 156-8550, Japan; syamaka@chs.nihon-u.ac.jp \\ * Correspondence: makoto@akita-pu.ac.jp \\ † Current address: National Institute for Environmental Studies, Tsukuba 305-8506, Japan.
}

check for

updates

Citation: Inoue, M.; Ugajin, A.; Kiguchi, O.; Yamashita, Y.; Komine, M.; Yamakawa, S. Effects of the Tibetan High and the North Pacific High on the Occurrence of Hot or Cool Summers in Japan. Atmosphere 2021, 12, 307. https://doi.org/ $10.3390 /$ atmos 12030307

Academic Editors: Corrado Camera and Georgios Zittis

Received: 19 January 2021

Accepted: 23 February 2021

Published: 26 February 2021

Publisher's Note: MDPI stays neutral with regard to jurisdictional claims in published maps and institutional affiliations.

Copyright: (c) 2021 by the authors. Licensee MDPI, Basel, Switzerland. This article is an open access article distributed under the terms and conditions of the Creative Commons Attribution (CC BY) license (https:/ / creativecommons.org/licenses/by/ $4.0 /)$.
Abstract: In this study, we investigated the effects of the Tibetan High near the tropopause and the North Pacific High in the troposphere on occurrences of hot or cool summers in Japan. We first classified Japan into six regions and identified hot and cool summer years in these regions from a 38-year sample (1980-2017) based on the monthly air temperature. To investigate the features of circulation fields over Asia during hot and cool summers in Japan, we calculated the composite differences (hot summer years minus cool summer years) of several variables such as geopotential height, which indicated significant high-pressure anomalies in the troposphere and lower stratosphere. These results suggest that both the North Pacific and the Tibetan Highs tend to extend to Japan during hot summer years, while cool summers seem to be associated with the weakening of these highs. We found that extension of the Tibetan High to the Japanese mainland can lead to hot summers in Northern, Eastern, and Western Japan. On the other hand, hot summers in the Southwestern Islands may be due to extension of the Tibetan High to the south. Similarly, the latitudinal direction of extension of the North Pacific High is profoundly connected with the summer climate in respective regions.

Keywords: hot summer; cool summer; Tibetan High; North Pacific High; statistical analysis

\section{Introduction}

Meteorological disasters, including drought, a cool summer, or heavy rain, have a serious effect on crop yields in Japan. Drought causes a fall in rice production due to inadequate and poorly distributed rainfall, and an exceptionally cool summer brings about low rice yields which can lead to considerable disturbances to rice markets. The Okhotsk High and the North Pacific High dominate the summer weather in East Asia including Japan [1-6]. The "Yamase" wind, a cool and moist air current originating in the Okhotsk High, induces large summer temperature variation, greatly influencing the summer climate in northeastern Japan $[3,7,8]$. On the other hand, the western stretch (i.e., extension to Japan) of the North Pacific High dominates the summer climate in East Asia [9,10], bringing hot and humid conditions. However, it is difficult to predict the summer weather in Japan from the development of only these two highs in the lower and middle troposphere because there are many factors, such as the El Niño-Southern Oscillation and phenomena in the upper atmosphere, that may drive temperature variability [11].

Recently, there has been discussion that the Tibetan High is an important factor in determining summer climate in Japan. This high is a warm, gigantic, anti-cyclonic circula- 
tion and covers East Asia from the upper troposphere to the lower stratosphere [12-14], and greatly influences the summer climate in East Asia [15]. This is characterized by a high-pressure system over the Tibetan Plateau, which is also called the South Asian High [16-18]. The temporal analyses revealed that the location of the upper tropospheric westerly jet core near the northern periphery of the Tibetan High changed rapidly from $140^{\circ} \mathrm{E}$ to $90^{\circ} \mathrm{E}$ during the plum rain period over East Asia [19,20]. It was indicated that cool summers are profoundly related to enhancement of the Okhotsk High and weakening of the North Pacific and Tibetan Highs [21]. Yamakawa [22] showed that strengthening of the Tibetan High associated with the eruption of Mt. Pinatubo led to a hot summer in East Asia. The effects of interannual changes in the Tibetan High on the climate were investigated by Nagano et al. [15], who revealed a recent cooling trend over Northern Japan with the weakening of the Tibetan High since 1992. Owada and Ishikawa [23] showed that the center of the Tibetan High was located around the Tibetan Plateau during hot summer in East Asia, whereas it was located near the Iranian Plateau during cool summer. The Japan Meteorological Agency (JMA) reported that, in 2013, Japan experienced an extremely hot summer due to the enhanced Pacific High and the Tibetan High associated with a significantly active Asian monsoon [24]. However, few studies have investigated the characteristics of drought and cool summer years in recent decades. In this study, we clarify the influences of the Tibetan High and North Pacific High on the occurrence of drought and cool summers in Japan by statistical analyses of the atmospheric circulation fields during a 35-year period not only in the lower atmosphere but also near the tropopause. In addition, we examine how the direction of extension of these highs affects the summer climate in each region of Japan.

\section{Data and Analysis Methods}

\subsection{Surface air Temperature data and Definitions of Hot and Cool Summer Years}

To define hot and cool summer years in Japan, we used monthly surface air temperature data available via the JMA website [25]. We classified Japan into six regions, the Sea of Japan side of Northern Japan (NJJ), the Pacific side of Northern Japan (NJP), Eastern Japan (EJ), Western Japan (WJ), the Northeastern part of the Southwest Islands (SIN), and the Southwestern part of the Southwest Islands (SIS). Table 1 and Figure 1 list the meteorological stations and show the map of each region, respectively. The selected stations are uniformly distributed over the whole of Japan. For instance, NJJ consists of ten stations located in the Sea of Japan side of Hokkaido prefecture and Tohoku district.

Table 1. Meteorological stations for the six regions of Japan defined in this study.

\begin{tabular}{cc}
\hline Region & Name of Stations \\
\hline $\begin{array}{c}\text { the Sea of Japan side, Northern Japan (NJ) } \\
\text { the Pacific side, Northern Japan (NJP) }\end{array}$ & $\begin{array}{c}\text { Haboro, Rumoi, Iwamizawa, Sapporo, Esashi, Fukaura, Akita, Sakata, Shinjo, } \\
\text { Yamagata }\end{array}$ \\
Eastern Japan (EJ) & $\begin{array}{c}\text { Nemoro, Kushiro, Obihiro, Hiroo, Mutsu, Hachinohe, Miyako, Morioka, Ohunato, } \\
\text { Ishinomaki, Sendai, Fukushima, Onahama } \\
\text { Mito, Utsunomiya, Maebashi, Tokyo, Katsura, Kofu, Takada, Toyama, Suwa, } \\
\text { Takayama, Fukui, Nagoya, Shizuoka }\end{array}$ \\
Western Japan (WJ) & $\begin{array}{c}\text { Hikone, Wakayama, Toyooka, Yonago, Hamada, Takamatsu, Matsuyama, Kochi, } \\
\text { Fukuoka, Nagasaki, Kumamoto, Nobeoka, Makurazaki } \\
\text { Yakushima, Naze }\end{array}$ \\
$\begin{array}{c}\text { Northeastern part of Southwest Islands (SIN) } \\
\text { Southwestern part of Southwest Islands (SIS) }\end{array}$ & Minamidaito, Naha, Ishigakijima, Yonagunijima \\
\hline
\end{tabular}

Figure 2 shows the interannual variation in surface temperature in NJJ, NJP, EJ, WJ, SIN, and SIS during the 38-year period of 1980-2017. The year 1994 had a typical hot summer, in which the surface temperature was higher at most locations [26]. This condition led to rainfall shortage and restrictions of municipal supply service in Japan. On the other hand, temperatures in 1993 and 2003 were lower, and these seriously damaged the Japanese rice crop. The summer weather in 2010 was quite hot, and much of the rice crop 
was damaged due to extreme heat [27]. For each region, 10 hottest years were defined as hot summer years, and 10 coolest years were defined as cool summer years based on the surface temperature data during the studied period. The classification results for the six regions are listed in Table 2.

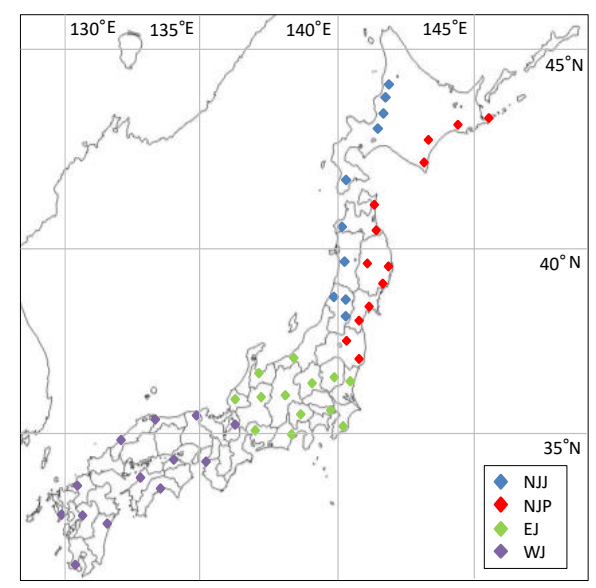

(a)



(b)

Figure 1. Spatial distribution of meteorological stations for each region of (a) the Japanese mainland and (b) the Southwestern Islands used for the classification of hot and cool summer years in this study.

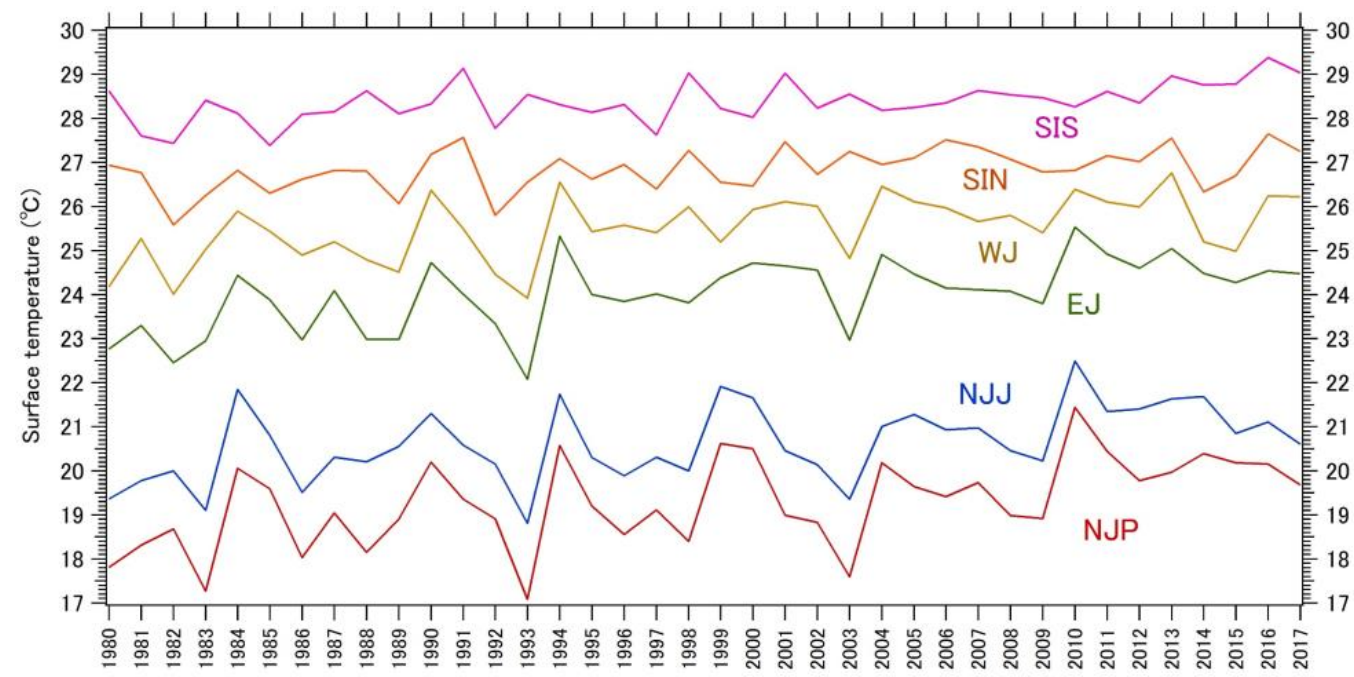

Figure 2. Temporal variation in surface temperature for summer (June-August) in six regions of Japan. The blue, brown, green, gold, orange, and pink lines show the surface temperature in NJJ, NJP, EJ, WJ, SIN, and SIS, respectively.

\subsection{Reanalysis Data for Composite Maps and Analysis Procedure}

To examine the features of the large-scale circulation associated with higher and lower temperatures in Japan in Northern Hemisphere summers (June, July, and August) from 1980 to 2017, we used monthly reanalysis data (geopotential height, meridional wind, and vertical $\mathrm{p}$ velocity) with a horizontal resolution of $2.5^{\circ} \times 2.5^{\circ}$ derived from the National Centers for Environmental Prediction/National Center for Atmospheric Research global atmospheric reanalysis data [28]. In addition, we utilized the monthly precipitation data with a horizontal resolution of $2.5^{\circ} \times 2.5^{\circ}$ provided by the Climate Prediction Center Merged Analysis of Precipitation [29] over the same period. We calculated the difference between hot and cool summer years (i.e., hot summer years minus cool summer years) for selected variables. In addition, we evaluated the statistical significance of these composite 
differences using Welch's $t$ test with the significance level at 95\%. This method has been used to clarify the features of the upper atmosphere [30,31].

Table 2. Classification results for hot and cool summer years in six regions of Japan.

\begin{tabular}{|c|c|c|}
\hline & Hot Summer Years & Cool Summer Years \\
\hline the Sea of Japan side, Northern Japan (NJJ) & $\begin{array}{l}1984,1990,1994,1999,2000,2010,2011, \\
2012,2013,2014\end{array}$ & $\begin{array}{c}\text { 1980, 1981, 1982, 1983, 1986, 1993, } \\
1996,1998,2002,2003\end{array}$ \\
\hline the Pacific side, Northern Japan (NJP) & $\begin{array}{l}\text { 1990, 1994, 1999, 2000, 2004, 2010, 2011, } \\
\text { 2014, 2015, } 2016\end{array}$ & $\begin{array}{c}\text { 1980, 1981, 1982, 1983, 1986, 1988, } \\
1993,1996,1998,2003\end{array}$ \\
\hline Eastern Japan (EJ) & $\begin{array}{l}\text { 1990, 1994, 2000, 2001, 2002, 2004, 2010, } \\
\text { 2011, 2012, } 2013\end{array}$ & $\begin{array}{c}\text { 1980, 1981, 1982, 1983, 1986, 1988, } \\
\text { 1989, 1992, 1993, } 2003\end{array}$ \\
\hline Western Japan (WJ) & $\begin{array}{c}\text { 1990, 1994, 2001, 2004, 2005, 2010, 2011, } \\
\text { 2013, 2016, } 2017\end{array}$ & $\begin{array}{c}\text { 1980, 1982, 1983, 1986, 1988, 1989, } \\
1992,1993,2003,2015\end{array}$ \\
\hline Northeastern part of Southwest Islands (SIN) & $\begin{array}{c}\text { 1990, 1991, 1998, 2001, 2003, 2006, 2007, } \\
\text { 2013, 2016, } 2017\end{array}$ & $\begin{array}{c}1982,1983,1985,1989,1992,1993, \\
1997,1999,2000,2014\end{array}$ \\
\hline Southwestern part of Southwest Islands (SIS) & $\begin{array}{l}1980^{*}, 1988^{*}, 1991,1998,2001,2007,2013, \\
2014,2015,2016,2017\left(^{*} \text { joint } 10 \text { th place }\right)\end{array}$ & $\begin{array}{c}\text { 1981, 1982, 1984, 1985, 1986, } 1989, \\
1992,1995,1997,2000\end{array}$ \\
\hline
\end{tabular}

\section{Results}

\subsection{North Pacific Subtropical High and Tibetan High}

We first show the features of the atmospheric field over Asia and Eurasia in summer. Figure 3 indicates the spatial distribution of geopotential height at several altitudes in the hot (left panels) and cool summer years (right panels). This distribution shows the mean values of ten years in each altitude. The North Pacific subtropical high is centered around the Hawaiian Islands at $500 \mathrm{hPa}$ in the middle troposphere and at $850 \mathrm{hPa}$ in the lower troposphere (Figure $3 b, c, e, f)$. This high greatly influences the summer climate in East Asia including Japan $[4,5,32]$. At $150 \mathrm{hPa}$ in the tropopause, we find the center of the Tibetan High (Figure 3a,d) which is a warm, gigantic, anti-cyclonic circulation that covers East Asia from the upper troposphere to the lower stratosphere [12-15]. The Tibetan High extends to the west of India and can be explained as a Rossby wave response to the heating over India $[33,34]$. As noted in Section 1, the Tibetan High has a crucial effect on summertime weather in Japan, though it is hard to discuss the differences between the hot summer years and cool summer years based on the distribution of mean values (i.e., Figure 3). We therefore calculate the composite differences between the both years in the next section.

\subsection{Extension of the Tibetan High in Hot or Cool Summer Years}

Now, we shall examine how the occurrence of hot or cool summers in Japan is connected with atmospheric circulation fields in the broad Asian monsoon regions. Figure 4a shows the composite differences in geopotential height at $150 \mathrm{hPa}$ between hot and cool summer years in NJJ. We find significant high-pressure anomalies around Japan, which reflects stronger eastward extension (i.e., toward Japan) of the Tibetan High centered near the northern part of India (Figure 3a,b) in hot summer years than in cool ones. Striking positive anomalies develop over the Tian Shan Mountains $\left(80^{\circ} \mathrm{E}\right)$ and west Asia $\left(30-50^{\circ} \mathrm{N}\right)$, located at the same latitude band as the Japanese islands. On the other hand, low pressure anomalies can be seen in subtropical regions (south of $30^{\circ} \mathrm{N}$ ). We here calculated the average and standard deviation of geopotential height at $150 \mathrm{hPa}$ around Northern Japan $\left(35-45^{\circ} \mathrm{N}, 60-90^{\circ} \mathrm{E}\right)$ for hot summer years (10 years) and cool summer years (10 years) in $\mathrm{NJJ}$. The average \pm standard deviation of geopotential height during hot summer years and cool summer years were $14,147 \pm 22 \mathrm{~m}$ and $14,103 \pm 20 \mathrm{~m}$, respectively. Thus, the difference between hot and cool summer years was approximately $44 \mathrm{~m}$ over Northern Japan. The distribution of geopotential height differences between hot and cool summer years in NJP is similar to that in NJJ (Figure 4a,b). This means that eastward extension of the Tibetan High is an important factor in agrometeorology and crop growth in both the Sea of Japan and Pacific sides of Northern Japan. Figure 4c shows the geopotential height 
differences at $150 \mathrm{hPa}$ between hot and cool summer years in EJ. Significant positive anomalies are present in East Asia, including Japan and Mongolia. By contrast, low pressure anomalies are dominant in the subtropics such as southern China. This characteristic is also found in the distribution of geopotential height difference in WJ (Figure 4d). We consider the mechanisms of hot and cool summers that occur in Eastern Japan to be extremely similar to those in Western Japan. Figure 4e,f show the composite differences between hot and cool summer years in SIN and SIS, respectively. Positive anomalies are seen in most parts of Asia and Eurasia, including Japan. Particularly, for hot summer years in SIS, significant high-pressure anomalies develop over the Ogasawara Islands and the Mariana Islands located southeast of the Japanese mainland. These results suggest that the Tibetan High tends to extend to the south of Japan during hot summers in the Southwest Islands compared to those of Northern, Eastern, and Western Japan.

(a)

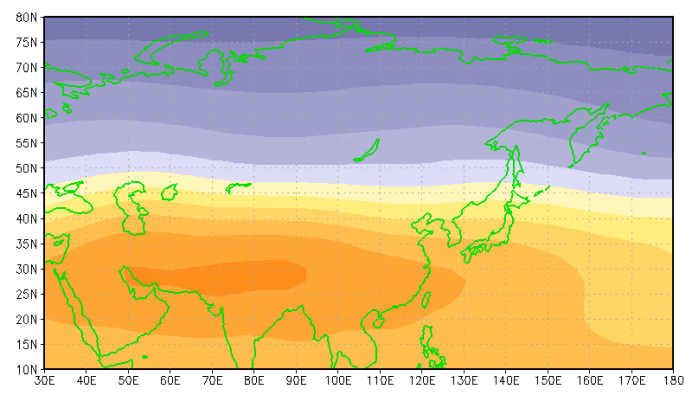

(b)
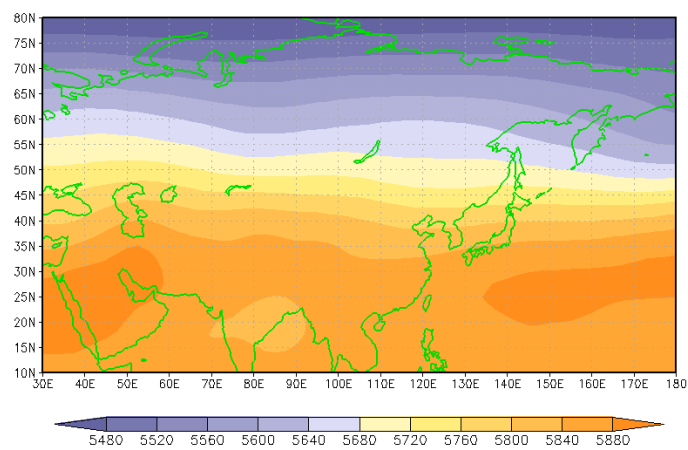

(c)

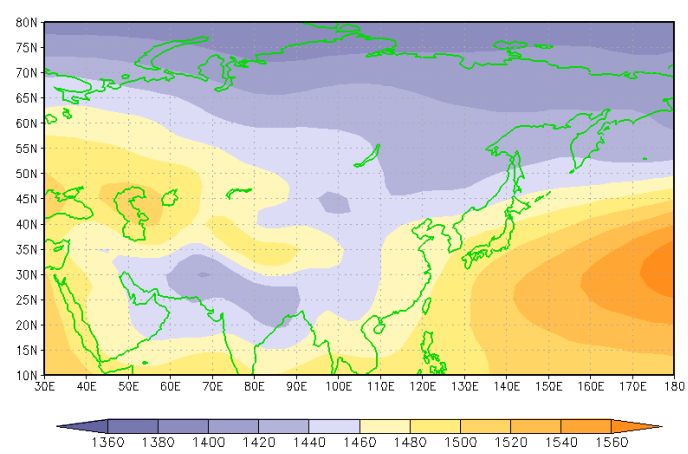

(d)

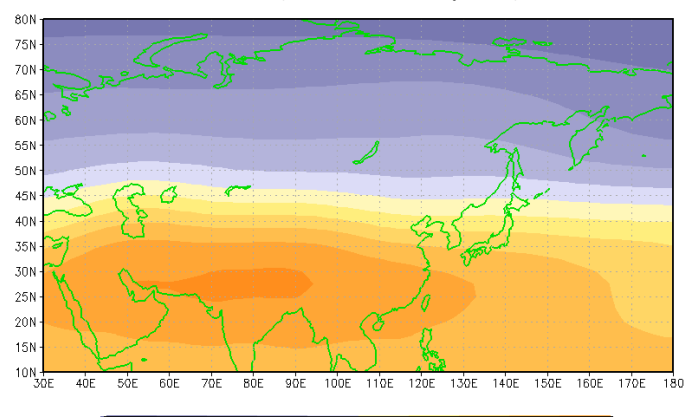

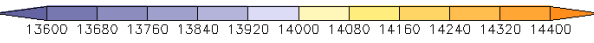

(e) Z500 (cool summer years)

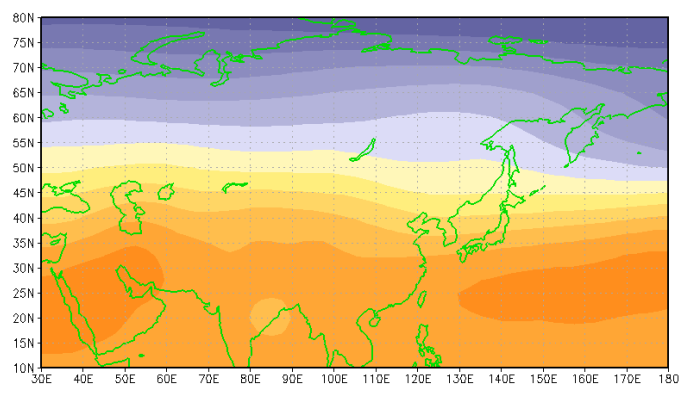

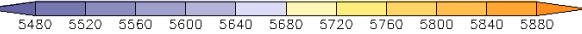

(f)

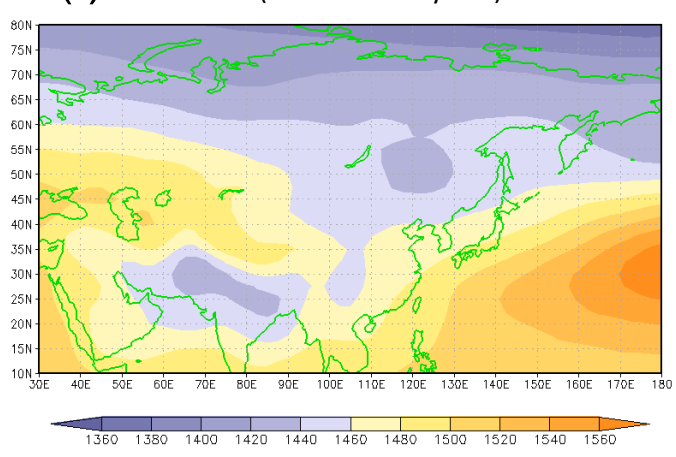

Figure 3. Spatial distribution of geopotential height (in m) at (a,d) $150 \mathrm{hPa},(\mathbf{b}, \mathbf{e}) 500 \mathrm{hPa}$, and (c,f) $850 \mathrm{hPa}$ for hot summer years (10 years) and cool summer years (10 years), respectively, in the Sea of Japan side of Northern Japan (NJJ). 
(a)

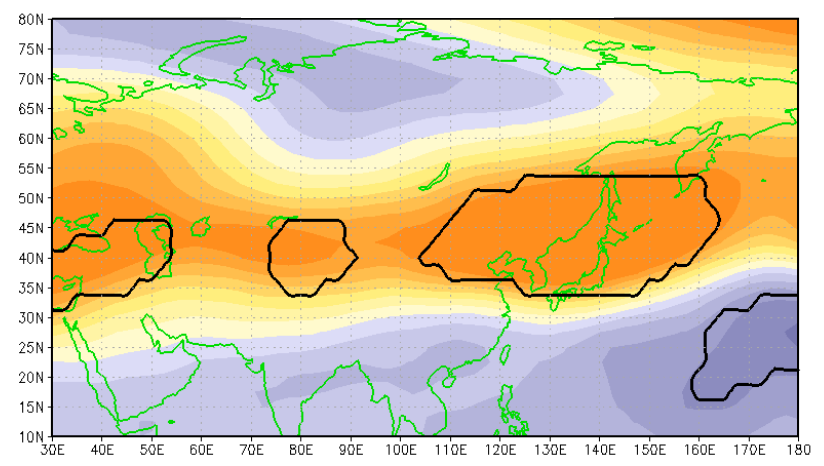

(b)



(c)


(d)

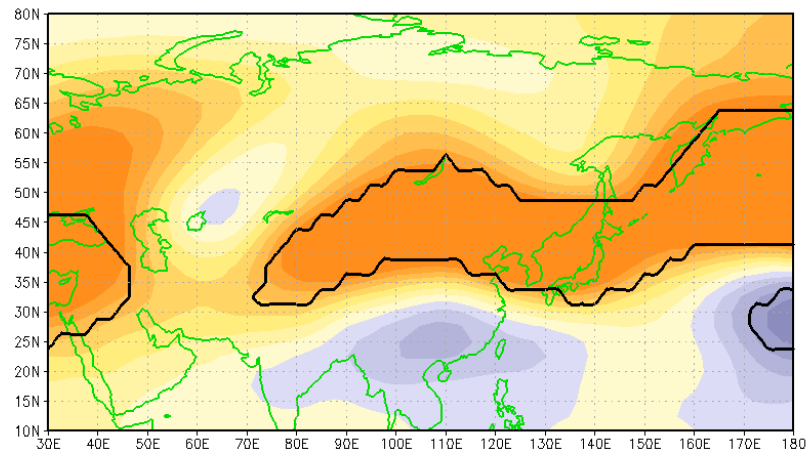

(e)

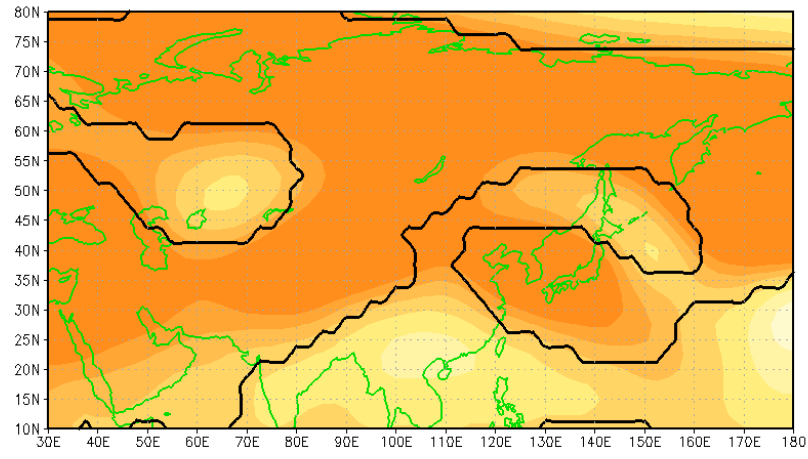

(f)



Figure 4. Composite differences in geopotential height (in $\mathrm{m}$ ) at $150 \mathrm{hPa}$ between hot and cool summer years in (a) the Sea of Japan side of Northern Japan (NJJ), (b) the Pacific side of Northern Japan (NJP), (c) Eastern Japan (EJ), (d) Western Japan (WJ), (e) the Northeastern part of the Southwest Islands (SIN), and (f) the Southwestern part of the Southwest Islands (SIS). The borders of regions that reached a significance of $95 \%$ are shown with thick lines.

\subsection{Extension of the North Pacific High in Hot or Cool Summer Years}

Next, we focus on the extension of the North Pacific High centered around the Hawaiian Islands. Figure 5 a shows the composite differences in geopotential height at $850 \mathrm{hPa}$ between hot and cool summer years in NJJ. We find significant high-pressure anomalies around Japan, which reflects stronger westward extension (i.e., toward Japan) of the North 
Pacific High centered on Hawaii (Figure 3c,f) in hot summer years than in cool ones. The average \pm standard deviation of geopotential height at $850 \mathrm{hPa}$ over Northern Japan $\left(35-45^{\circ} \mathrm{N}, 60-90^{\circ} \mathrm{E}\right)$ during hot summer years and cool summer years were $1479 \pm 8 \mathrm{~m}$ and $1471 \pm 4 \mathrm{~m}$, respectively. The difference between hot and cool summer years was about $8 \mathrm{~m}$ over Northern Japan. The distribution of geopotential height anomalies in NJP is also similar to that in NJJ (Figure 5b). Composite anomaly maps of hot and cool summer years in EJ and WJ reveal positive anomalies over those two regions, and negative anomalies around the Okhotsk Sea (Figure 5c,d). Significant high-pressure anomalies can be seen in southern parts of Kyushu district (Figure 5e,f).

(a)



(b)

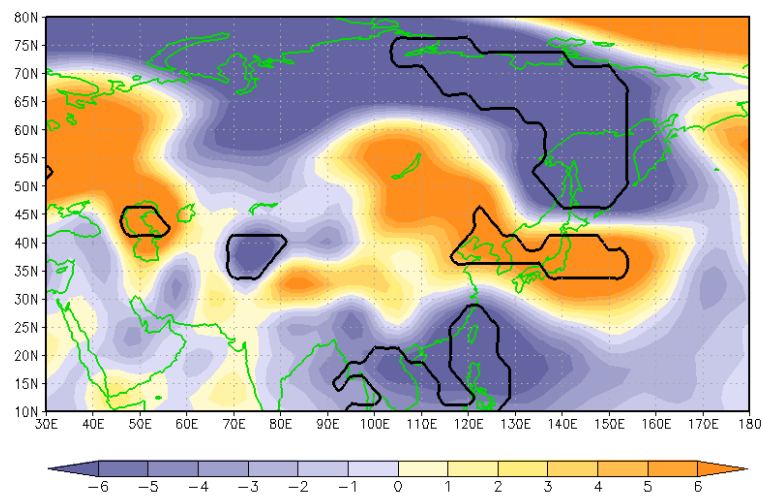

(c)

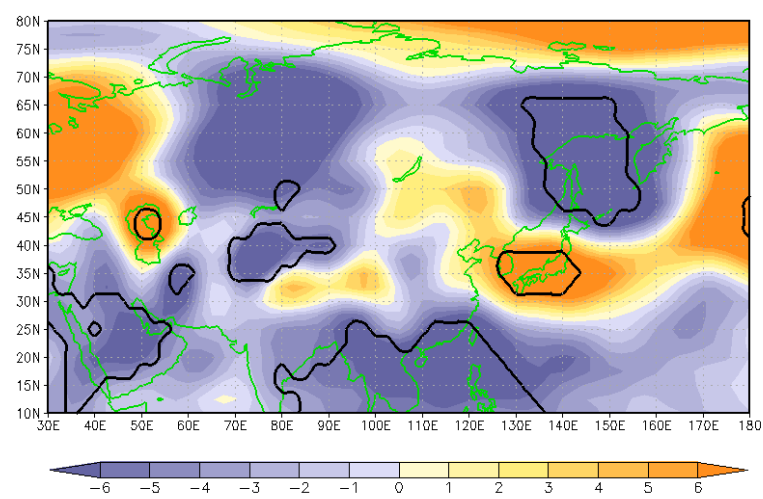

(d)

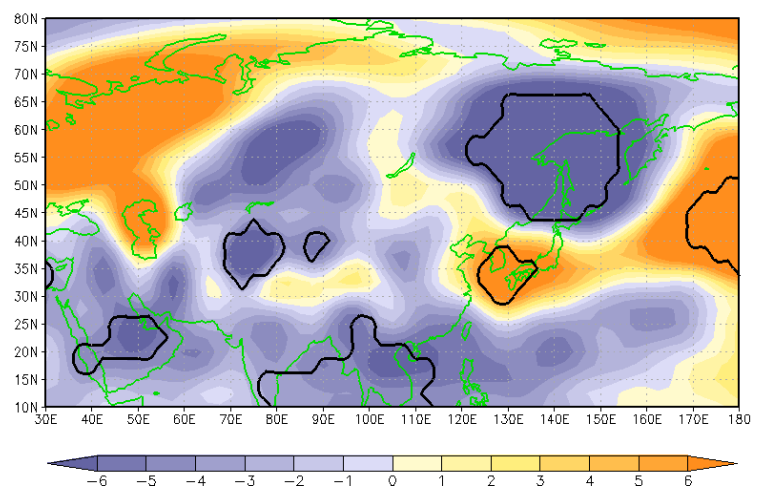

(e)

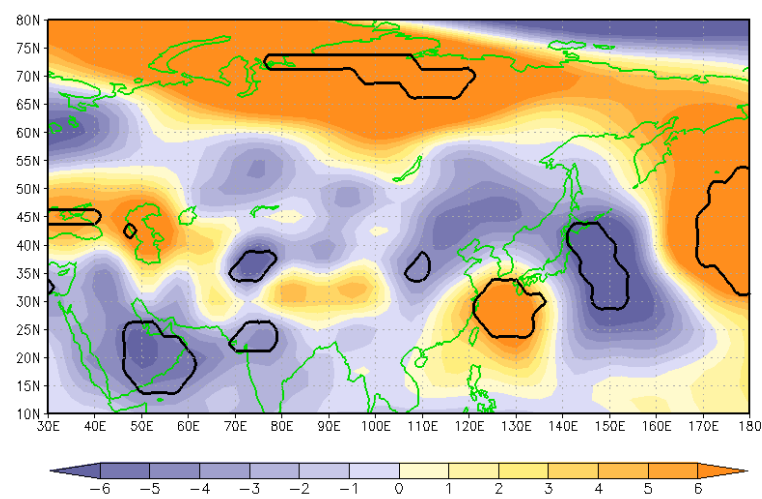

(f)

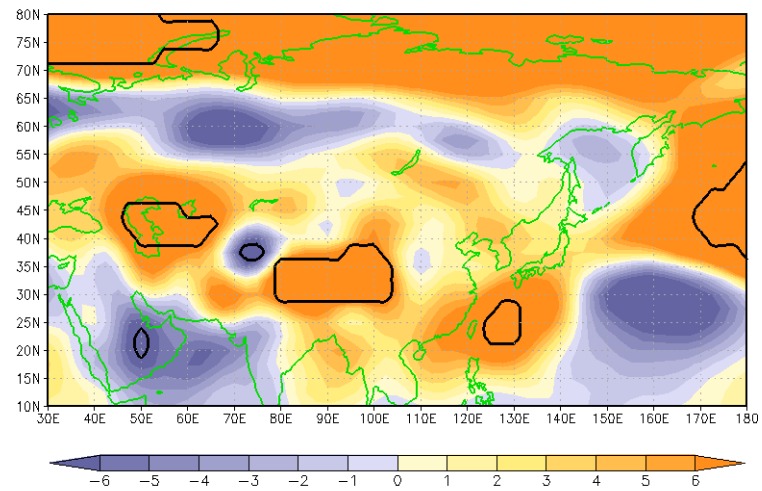

Figure 5. Composite differences in geopotential height (in $\mathrm{m}$ ) at $850 \mathrm{hPa}$ between hot and cool summer years in (a) NJJ, (b) NJP, (c) EJ, (d) WJ, (e) SIN, and (f) SIS. The borders of regions that reached a significance of 95\% are shown with thick lines. 
To clarify the characteristics of the large-scale circulation associated with high pressure system over Japan, we investigated the distributions of geopotential height, vertical flow, and precipitation. Here we focus on the North Pacific High extension in hot and cool summer years in NJJ, WJ, and SIS as representatives of Northern Japan, Western Japan, and the Southwestern Islands, respectively (Figures 6-8). Figure 6a shows the composite differences in geopotential height at $500 \mathrm{hPa}$ in NJJ. We found significant high-pressure anomalies in the middle troposphere over the Japanese islands, including Hokkaido. This means that the North Pacific High extended to Japan during hot summers in Northern Japan, unlike during cool summers. The distribution of precipitation anomalies shows negative and positive anomalies over Japan and the Philippines, respectively (Figure $6 \mathrm{~b}$ ). These are consistent with ascent anomalies around the Philippine Sea at low latitude $\left(10-25^{\circ} \mathrm{N}\right)$ and descent anomalies around Japan $\left(30-40^{\circ} \mathrm{N}\right)$ in the troposphere (Figure $6 \mathrm{c}, \mathrm{d}$ ). We consider that hot summers tend to occur in Northern Japan due to extension of the North Pacific High over the Japanese mainland. For hot summers in Western Japan, significant high-pressure anomalies are seen over the Japanese mainland, as in Northern Japan (Figure 7a). However, whether the North Pacific High extends to Hokkaido during hot summers in Western Japan is unclear, compared to Northern Japan. There are positive and negative rainfall anomalies (Figure $7 \mathrm{~b}$ ), which are consistent with the distribution of ascent anomalies at low latitude $\left(10-20^{\circ} \mathrm{N}\right)$ and descent anomalies $\left(20-40^{\circ} \mathrm{N}\right)$ in the troposphere, respectively (Figure $7 \mathrm{c}, \mathrm{d}$ ). On the other hand, the analysis results for the Southwestern Islands reveal significant high-pressure anomalies in the broad region from the Philippine Sea to the Japanese islands (Figure 8a). The descent anomalies in the low and middle latitudes $\left(20-30^{\circ} \mathrm{N}\right)$ associated with low rainfall anomalies are striking (Figure 8b-d). These results indicate that extension of the North Pacific High to the south can lead to warming and drought in the Southwestern Islands.

(a)

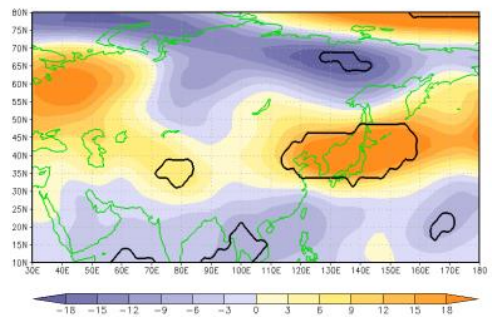

(b)

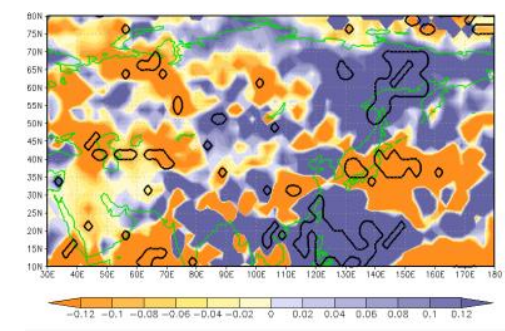

(c)

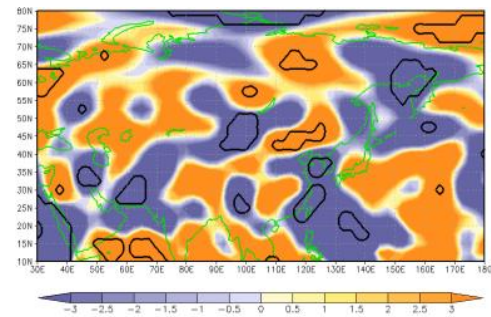

(d)

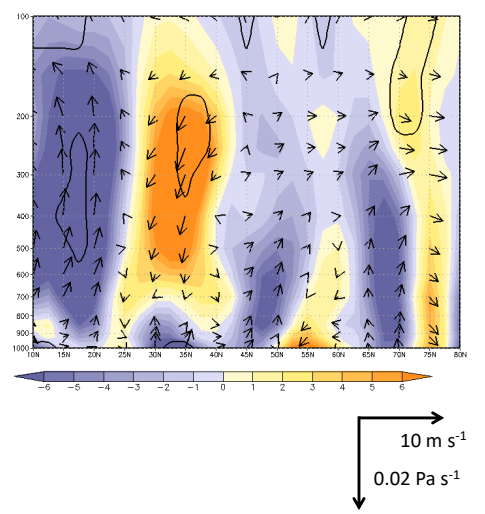

Figure 6. Composite differences in (a) geopotential height (in $\mathrm{m}$ ) at $500 \mathrm{hPa}$, (b) precipitation (in $\mathrm{mm}$ day $^{-1}$ ), and (c) vertical p-velocity (in $10^{-3} \mathrm{~Pa} \mathrm{~s}^{-1}$ ) at $500 \mathrm{hPa}$ between hot and cool summer years in NJJ. (d) Latitude-pressure cross-section of the composite differences in vertical p-velocity $\left(10^{-3} \mathrm{~Pa} \mathrm{~s}^{-1}\right)$ between hot and cool summer years in NJJ at $140^{\circ} \mathrm{E}$. Vectors show the composite differences in meridional-vertical flow (see legend for units). The borders of regions that reached a significance of $95 \%$ are shown with thick lines. 
(a)

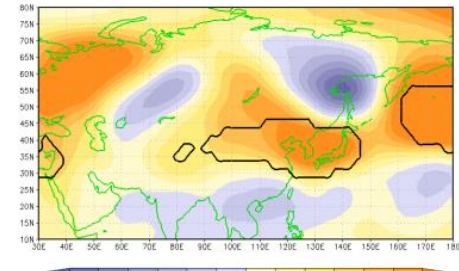

(b)

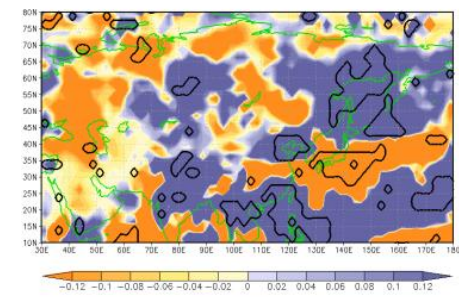

(c)



(d)

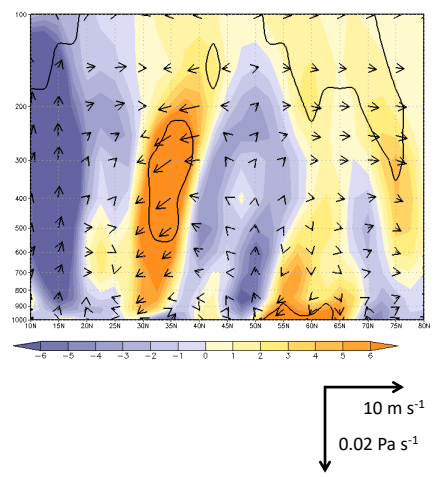

Figure 7. Composite differences in (a) geopotential height (in $\mathrm{m}$ ) at $500 \mathrm{hPa}$, (b) precipitation (in $\mathrm{mm} \mathrm{day}^{-1}$ ), and (c) vertical p-velocity (in $10^{-3} \mathrm{~Pa} \mathrm{~s}^{-1}$ ) at $500 \mathrm{hPa}$ between hot and cool summer years in WJ. (d) Latitude-pressure cross-section of the composite differences in vertical p-velocity (in $10^{-3} \mathrm{~Pa} \mathrm{~s}^{-1}$ ) between hot and cool summer years in WJ at $140^{\circ}$ E. Vectors show the composite differences in meridional-vertical flow (see legend for units). The borders of regions that reached a significance of $95 \%$ are shown with thick lines.

(a)

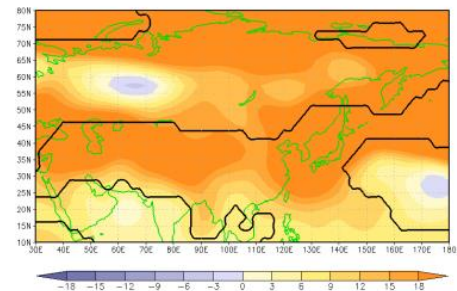

(b)

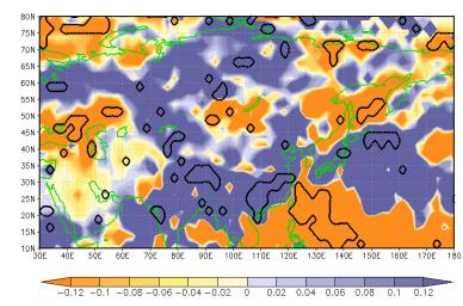

(c)

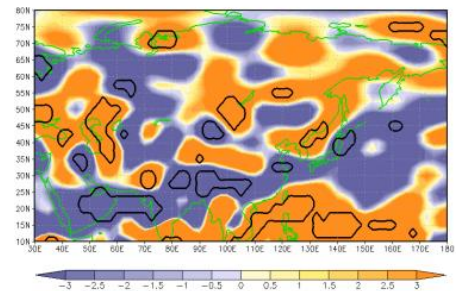

(d)

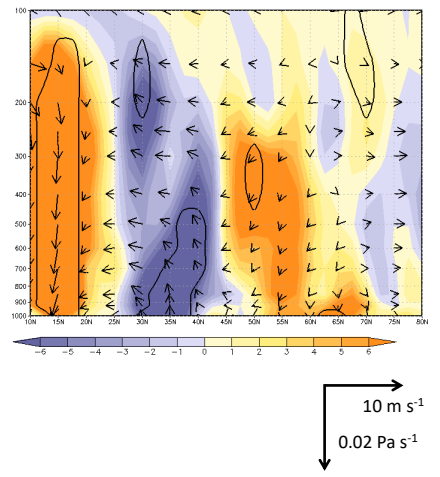

Figure 8. Composite differences in (a) geopotential height (in $\mathrm{m}$ ) at $500 \mathrm{hPa}$, (b) precipitation (in $\mathrm{mm}$ day $^{-1}$ ), and (c) vertical p-velocity (in $10^{-3} \mathrm{~Pa} \mathrm{~s}^{-1}$ ) at $500 \mathrm{hPa}$ between hot and cool summer years in SIS. (d) Latitude-pressure cross-section of the composite differences in vertical p-velocity (in $10^{-3} \mathrm{~Pa} \mathrm{~s}^{-1}$ ) between hot and cool summer years in SIS at $140^{\circ} \mathrm{E}$. Vectors show the composite differences in meridional-vertical flow (see legend for units). The borders of regions that reached a significance of $95 \%$ are shown with thick lines. 


\subsection{Relationships between the Extension of Two Highs and Occurrences of Hot or Cool Summers}

Figure 9 shows a schematic diagram of the longitudinal and vertical extensions of the Tibetan High near the tropopause and the North Pacific High in the troposphere during hot summers in Japan. We suggest that the enhanced Tibetan High and North Pacific High (i.e., a structure with two layers over Japan) can lead to adiabatic heating when air masses descend in the atmosphere, causing hot summers. Conversely, cool summers are linked to the weakening of the Tibetan High and the North Pacific High.

\section{lower stratosphere}

\section{Tibetan High}

troposphere

Tibet

Japan

Hawaii

Figure 9. Schematic diagram showing the longitudinal and vertical extensions of the Tibetan High and the North Pacific High during hot summers in Japan.

The relationship between the latitudinal direction of extension of the Tibetan High and the region where a hot summer occurs in Japan is summarized in Figure 10a. In hot summer years for the Japanese mainland, high pressure anomalies were seen at $150 \mathrm{hPa}$ over Japan. This means that hot summer in the mainland occurs due to extension to the north (i.e., the Japanese mainland) of the Tibetan High (Figure 10a). By contrast, extension to the south can lead to drought in the Southwestern Islands. Next, we focus on extension of the North Pacific High in the troposphere (Figure 10b). In hot summer years for Northern Japan, high pressure anomalies at $500 \mathrm{hPa}$ are observed in the Japanese islands. On the other hand, hot summer in the Southwestern Islands seems to occur with high pressure anomalies in the subtropical zone including the southern part of Japan. This might mean that the North Pacific High extends to the north during hot summers in the Japanese mainland, whereas hot summers in the Southwestern Islands occur due to extension to the south of the North Pacific High (Figure 10b). In other words, the summer climate in each region of Japan is profoundly controlled by the direction of extension of these two highs. 



Figure 10. Schematic diagram showing the relationships between the latitudinal direction of extension of (a) the Tibetan High and (b) the North Pacific High and the regions where hot summers occur in Japan.

\section{Summary}

This paper has presented the effects of the North Pacific High and the Tibetan High on occurrences of hot or cool summers in Japan. Japan was classified into six regions, and hot and cool summer years in these regions were extracted during a 38-year period (1980-2017). The features of the large-scale circulation in the troposphere and lower stratosphere and the precipitation distribution in hot and cool summer years were investigated using the National Centers for Environmental Prediction/National Center for Atmospheric Research reanalysis data and the Climate Prediction Center Merged Analysis of Precipitation data. In general, both the Tibetan High and North Pacific High tended to extend to Japan during hot summers in Northern Japan, Eastern Japan, Western Japan, and the Southwestern Islands. On the other hand, the occurrences of cool summers were associated with the weakening of these highs. Thus, the summer climate in each region of Japan is profoundly controlled by the extension of the Tibetan High and North Pacific High. It is important to monitor 
the behaviors of these highs for accurate prediction of extreme weather disasters such as droughts and cold weather which can seriously damage many crops. Further analyses on these highs from June through August may lead to great benefits to the agricultural and economic activity in summer.

Author Contributions: S.Y. conceived of the presented idea. M.I. took on the project administration and wrote the original draft. A.U. performed formal analysis and investigations. O.K. supervised the findings of this work and contributed to the writing-review and editing. Y.Y., M.K., and S.Y. participated in discussions and contributed to the writing-review and editing. All authors have read and agreed to the published version of the manuscript.

Funding: This research was supported by Grant-in-Aid for New faculty startup support of Akita Prefectural University.

Informed Consent Statement: Not applicable.

Data Availability Statement: Data used in this paper are available in a publicly accessible website: Monthly surface air temperature data for each region of Japan are available in the Japan Meteorological Agency at https:/ / www.data.jma.go.jp/obd/stats/etrn/index.php (accessed on 26 February 2021); Monthly global atmospheric reanalysis data are available from the National Centers for Environmental Prediction/National Center for Atmospheric Research at https:/ /psl.noaa.gov/data / gridded/data.ncep.reanalysis.pressure.html (accessed on 26 February 2021); Monthly precipitation data are available from the Climate Prediction Center Merged Analysis of Precipitation at https:/ / psl.noaa.gov/data/gridded/data.cmap.html (accessed on 26 February 2021).

Acknowledgments: We used the Grid Analysis and Display System for drawing part of figures. This study was conducted with financial support from Akita Prefectural University, Japan.

Conflicts of Interest: The authors declare no conflict of interest.

\section{References}

1. Kudoh, T. Characteristics of Okhotsk air mass during the typical Yamase period (1981.6.18 21). Tenki 1984, 31, 411-419. (In Japanese)

2. Bokura, T. The effect of the Yamase on cool-summer damage in Tohoku District. J. Agric. Met. 1997, 52, 957-960. [CrossRef]

3. Kanno, H. Classification of the Yamase (cold northeasterly wind around northeastern Japan) based upon its air-mass vertical structures. J. Meteorol. Soc. Jpn. 1997, 75, 1053-1071. [CrossRef]

4. Nishimori, M. Long-term temperature variability and cool (1993) and hot (1994) summer in Japan. Meteor. Res. Note 1997, 189, 199-216. (In Japanese)

5. Lu, R. Interannual variability of the Summertime North Pacific Subtropical High and its relation to atmospheric convection over the Warm Pool. J. Meteorol. Soc. Jpn. 2001, 79, 771-783. [CrossRef]

6. Ogi, M.; Tachibana, Y.; Yamazaki, K. The connectivity of the winter North Atlantic Oscillation (NAO) and the summer Okhotsk High. J. Meteorol. Soc. Jpn. 2004, 82, 905-913. [CrossRef]

7. Bokura, T. Observations of the special clouds on the lee side of Yamase wind. J. Agric. Met. 1975, 31, 1-5, (In Japanese with English Summary). [CrossRef]

8. Ninomiya, K.; Mizuno, H. Anomalously cold spell in summer over northeastern Japan caused by northeasterly wind from polar maritime air-mass. Part 1. EOF analysis of temperature variation in relation to the large-scale situation causing the cold summer. J. Meteorol. Soc. Jpn. 1985, 63, 845-857. [CrossRef]

9. Nishimori, M. Analysis of the characteristics of the occurrence of hot and cool summer in Japan. Tenki 1999, 46, 267-280. (In Japanese)

10. Wu, C.H.; Chou, M.D. Upper-tropospheric forcing on Late July Monsoon Transition in East Asia and the Western North Pacific. J. Clim. 2012, 25, 3929-3941. [CrossRef]

11. Yamakawa, S.; Inoue, M.; Suppiah, R. Relationships between solar activity and variations in SST and atmospheric circulation in the stratosphere and troposphere. Quarter. Int. 2016, 397, 289-299. [CrossRef]

12. Flohn, H. Large-scale aspects of the "summer monsoon" in South and East Asia. J. Meteorol. Soc. Jpn. 1957, 35A, 180-186. [CrossRef]

13. Terao, T. Relationships between the quasi-stationary Rossby waves in the subtropical jet and the mass and heat transport in the northern periphery of the Tibetan High. J. Meteorol. Soc. Jpn. 1999, 77, 1271-1286. [CrossRef]

14. Fujinami, H.; Yasunari, T. The seasonal and intraseasonal variability of diurnal cloud activity over the Tibetan Plateau. J. Meteorol. Soc. Jpn. 2001, 79, 1207-1227. [CrossRef]

15. Nagano, Y.; Kato, H.; Yamakawa, S. Recent cooling trend over northern Japan in August in relation to the weakening of the Tibetan high. J. Agric. Met. 2009, 65, 129-139. [CrossRef] 
16. Zhang, Q.; Wu, G.X.; Qian, Y.F. The bimodality of the $100 \mathrm{hPa}$ South Asia High and its relationship to the climate anomaly over East Asia in summer. J. Meteorol. Soc. Jpn. 2002, 80, 733-744. [CrossRef]

17. Owada, M.; Ishikawa, Y.; Kuroyanagi, Y.; Owada, H. Ebb and Flow of Influence Concerned with East-West Movement of South Asian High at 100hPa Pressure Field. Bull. Aichi Univ. Educ. 2006, 55, 23-28, (In Japanese with English Abstract).

18. Xue, X.; Chen, W.; Chen, S.; Zhou, D. Modulation of the connection between boreal winter ENSO and the South Asian high in the following summer by the stratospheric quasi-biennial oscillation. J. Geophys. Res. 2015, 120, 7393-7411. [CrossRef]

19. Zhang, Y.; Kuang, X.; Guo, W.; Zhou, T. Seasonal evolution of the upper-tropospheric westerly jet core over East Asia. Geophys. Res. Lett. 2006, 33, L11708. [CrossRef]

20. Zhang, Y.; Takahashi, M.; Guo, L. Analysis of the East Asian subtropical westerly jet simulated by CCSR/NIES/FRCGC coupled climate system model. J. Meteorol. Soc. Jpn. 2008, 86, 257-278. [CrossRef]

21. Wakahara, K.; Fujikawa, N. The feature of the weather of Japan and the circulation on cool summer in 1993 and hot summer in 1994. Meteorol. Res. Notes 1997, 189, 2-69. (In Japanese)

22. Yamakawa, S. The impact of the Pinatubo Eruption on global and regional climatic systems. J. Agric. Met. 1997, 52, 713-716. [CrossRef]

23. Owada, M.; Ishikawa, Y. An analysis in both pressures fields over East Asia and Northern Hemisphere in East Asian unusually summer. Geogr. Rep. 2005, 100, 19-28, (In Japanese with English Abstract).

24. Japan Meteorological Agency (JMA). Extreme Summer Conditions in Japan in 2013 -Summary of Analysis by the TCC Advisory Panel on Extreme Climatic Events. 2013. Available online: https:/ /ds.data.jma.go.jp/tcc/tcc/news/press_20130902.pdf (accessed on 4 January 2021).

25. Japan Meteorological Agency (JMA) Website. Weather Observation Data. Available online: https://www.data.jma.go.jp/obd/ stats/etrn/index.php (accessed on 25 February 2021).

26. Ishigooka, Y.; Kuwagata, T.; Nishimori, M.; Hasegawa, T.; Ohno, H. Spatial characterization of recent hot summers in Japan with agro-climatic indices related to rice production. J. Agric. Met. 2011, 67, 209-224. [CrossRef]

27. Kanno, H. Strongly negative correlation between monthly mean temperatures in April and August since 1998 in Northern Japan. J. Meteorol. Soc. Jpn. 2013, 91, 355-373. [CrossRef]

28. Kalnay, E.; Kanamitsu, M.; Kistler, R.; Collins, W.; Deaven, D.; Gandin, L.; Joseph, D. The NCEP/NCAR 40-year reanalysis project. Bull. Am. Meteorol. Soc. 1996, 77, 437-471. [CrossRef]

29. Xie, P.; Arkin, P.A. Global precipitation: A 17-year monthly analysis based on gauge observations, satellite estimates, and numerical model outputs. Bull. Am. Meteorol. Soc. 1997, 78, 2539-2558. [CrossRef]

30. Inoue, M.; Takahashi, M.; Naoe, H. Relationship between the stratospheric quasi-biennial oscillation (QBO) and tropospheric circulation in northern autumn. J. Geophys. Res. 2011, 116, D24115.

31. Inoue, M.; Takahashi, M. Connections between the stratospheric quasi-biennial oscillation and tropospheric circulation over Asia in northern autumn. J. Geophys. Res. 2013, 118, 10740-10753. [CrossRef]

32. Kawatani, Y.; Ninomiya, K.; Tokioka, T. The North Pacific subtropical high characterized separately for June, July, and August: Zonal displacement associated with submonthly variability. J. Meteorol. Soc. Jpn. 2008, 86, 505-530. [CrossRef]

33. Gill, A.E. Some simple solutions for heat-induced tropical circulation. Q. J. Roy. Meteorol. Soc. 1980, 106, 447-462. [CrossRef]

34. Inoue, M.; Takahashi, M. Connection between the Asian summer monsoon and stratosphere-troposphere circulation over the Asian region. J. Meteorol. Soc. Jpn. 2009, 87, 119-138. [CrossRef] 